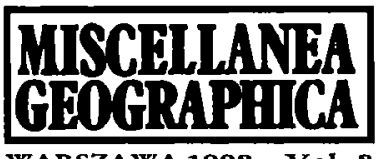

WARSZA WA 1998 Vol. 8

Mirosław Bogacki, Pham Minh Tan

\title{
TYPES OF CONTEMPORARY RELIEF MODELLING PROCESSES IN VIETNAM
}

The significant natural differentiation of Vietnam has the dominating influence on the character and intensity of the contemporary morphological processes and on the differentiation of types of relief modelling. The surface of Vietnam is being transformed by the geodynamic processes acting in the open system of chemical and physical modelling of relief.

Generally speaking the denudation balance on the ridges and slopes is everywhere negative. Erosion exceeds accumulation in the mountains and on the uplands. A part of the matter is being transported over significant distances. The measure of mechanical denudation in relief modelling is constituted by the quantity of washout on the slopes in tons per hectare $(\mathrm{t} / \mathrm{ha})$ and by the indicator of carry away transport in tons per square kilometer per year $\left(\mathrm{t} / \mathrm{km}^{2} /\right.$ year $)$.

Three types of relief modelling can be distinguished in Vietnam on the basis of the analysis of the denudation balance of the dominating morphodynamic processes and their intensity, namely the degradation type, the agradation type, and the degradation-agradation type, along with a number of subtypes (Fig. 1).

\section{THE DEGRADATION TYPE}

The average value of the denudation indicator for the whole of Vietnam is $0.14 \mathrm{~m}^{-3} /$ year. The average magnitude of mechanical denudation is estimated for the country at $260-360 \mathrm{t} / \mathrm{km}^{2} /$ year (Le Duc An, 1985). The maximum value of denudation exceeding $450 \mathrm{t} / \mathrm{km}^{2} /$ year is observed within Lai Chau province, while the minimum value - within the area of Hun Lung in Cao Lang province - does not exceed $40 \mathrm{t} / \mathrm{km}^{2} /$ year. The lowest value of degradation in the mountainous and upland areas is noted on the basaltic uplands, although they feature the highest intensity of the weathering process $(0.03-0.05 \mathrm{~mm} /$ year $)$.

The degradation type occupies the majority of the country's surface. Depending upon the intensity of morphological processes we can distin- 


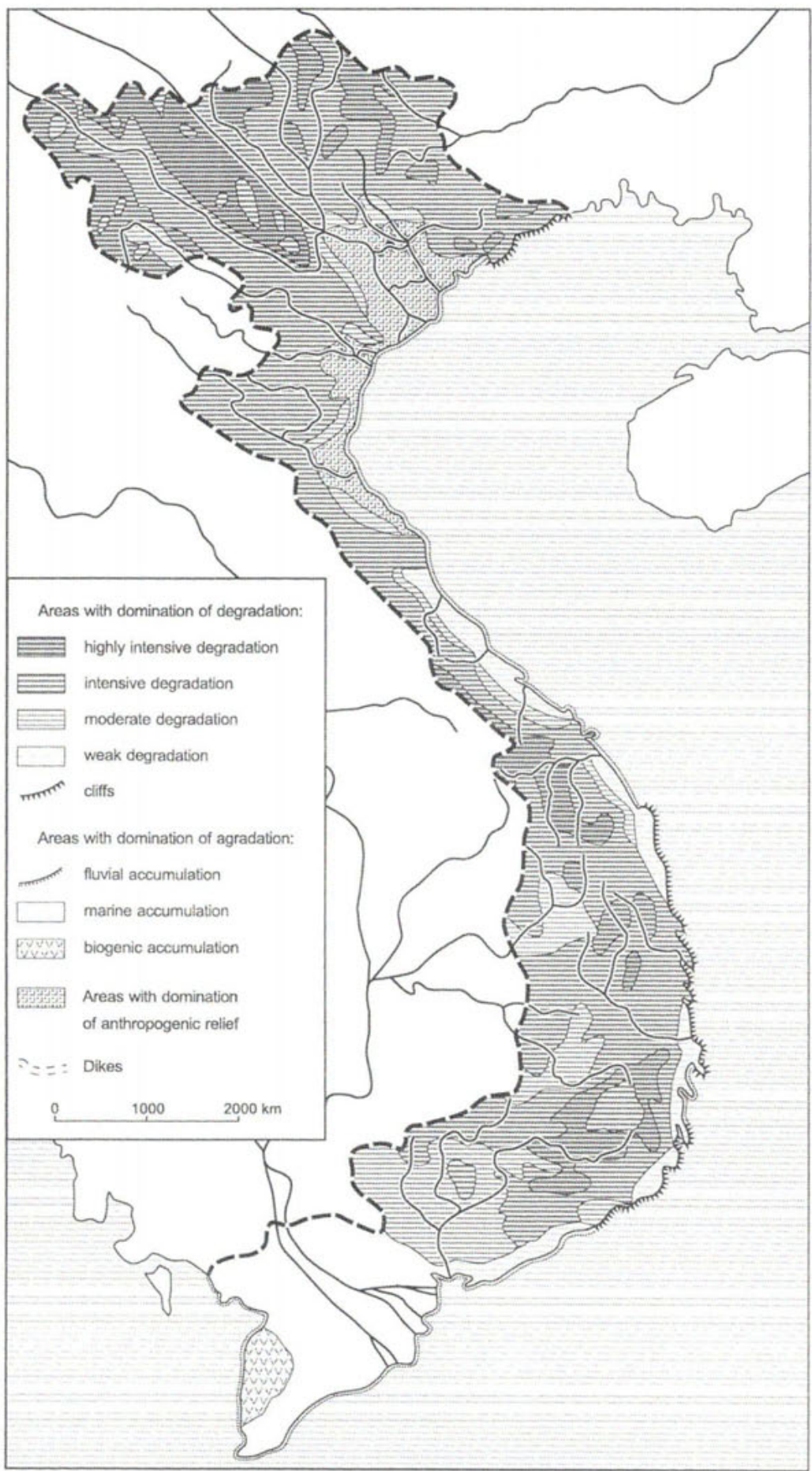


guish their four subtypes, featuring, respectively, very strong, strong, moderate and feeble intensity of the processes.

The areas featuring very high intensity of processes include the forestless mountain areas and mountain slopes taken for cultivation of corn, manioc and non-irrigated rice. These areas are primarily modelled by washout, gully erosion and mass movements. The intensity of processes displays a distinct correlation with human activity. The indicator of denudation of slopes ranges between 0.039 and $37 \mathrm{~mm} /$ year (Nguyen Vi Dan, 1986). The magnitude of gully erosion is estimated at $50 \mathrm{~mm} /$ year (Nguyen Vi Dan, 1986), while the magnitude of river erosion attains $10 \mathrm{~mm} /$ year (Le Duc An, 1985). The denudational balance of the system of physical relief modelling is at more than $400 \mathrm{t} / \mathrm{km}^{2} /$ year (Vi Van Vi, 1983), while the balance of chemical denudation amounts to $35-70 \mathrm{t} / \mathrm{km}^{2} /$ year (Le Duc An, 1985). The general denudational balance of the areas considered can thus be estimated at more than $435 \mathrm{t} / \mathrm{km}^{2} /$ year.

Natural forests exist yet in Vietnam in high mountains, where slopes are very steep, and precipitation is very abundant. Besides this, the economic activity (roads, felling) is conducive to the development of contemporary morphological processes. The magnitude of denudation on the forested mountain areas attains $180-225 \mathrm{t} / \mathrm{km}^{2} /$ year. Relief is modelled here mainly by creeping, line erosion and leaching.

The strongly degraded areas encompass foothills, low mountains as well as high river terraces covered with savannas and taken for cultivation. The processes appearing here include primarily washout, gully erosion, mass movements and leaching. The denudation indicator within the foothills is on the average equal $0.039 \mathrm{~mm} / y e a r$ (Nguyen Vi Dan, 1986). The magnitude of the balance of mechanical denudation attains $180-200 \mathrm{t} / \mathrm{km}^{2} /$ year, while the magnitude of chemical denudation $-25-55 \mathrm{t} / \mathrm{km}^{2} /$ year. The summary balance of denudation can thus be estimated at $205-255 \mathrm{t} / \mathrm{km}^{2} /$ year.

The areas featuring high intensity of geodynamic processes include limestone uplands. The indicator of chemical denudation is estimated there at $0.049 \mathrm{~mm} /$ year (Nguyen Vi Dan, 1986). The balance of mechanical denudation for these areas ranges between 35 and $45 \mathrm{t} / \mathrm{km}^{2} /$ year, while the magnitude of chemical denudation - between 120 and $160 \mathrm{t} / \mathrm{km}^{2} /$ year. Total balance of denudation processes amounts therefore to $155-205 \mathrm{t} / \mathrm{km}^{2} /$ year.

The moderate intensity of degradation processes is observed within the areas founded on basalts, on the river and sea terraces, and in inter-montane bowls with low annual precipitation (below $1200 \mathrm{~mm}$ ). They are modelled by washout and leaching. This type of relief has a moderately negative denudational balance. The magnitude of total denudation amounts there to 80-115 $\mathrm{t} / \mathrm{km}^{2} /$ year, with the share of chemical denudation attaining $45-70$ $\mathrm{t} / \mathrm{km}^{2} /$ year, and of the mechanical denudation $-35-45 \mathrm{t} / \mathrm{km}^{2} /$ year. The denudation indicator for slopes attains $0.016 \mathrm{~mm} / \mathrm{year}$ (Le Duc An, 1985).

The areas featuring feeble degradation include seaside lowlands modelled by washout and leaching. Total denudation is estimated here at $60 \mathrm{t} / \mathrm{km}^{2} / \mathrm{year}$. 
THE AGRADATION TYPE

The agradation processes take place with varying intensity over the area of Vietnam. There is lack of adequate data, though, on their intensity. We can generally distinguish three subtypes of agradation: fluvial, marine and biogenic. The areas with domination of fluvial accumulation include river mouths. Marine accumulation appears locally along the coast, mainly along the stretch between Tra $\mathrm{Li}$ and Lach Truong and in the vicinity of Ca Man. Biogenic accumulation occurs first of all within the area of U Minh in the delta of Mekong river.

THE DEGRADATION-AGRADATION TYPE

The degradation-agradation type of relief modelling has the anthropogenic character and appears on the industrial, urbanized and intensively agriculturally used areas. A very characteristic example is provided by the relief of river deltas, cut through by numerous canals, ditches and artificial reservoirs, accompanied by dikes and weirs of various dimensions, separating paddy rice fields.

Dams and dikes started to be constructed in the delta of Red River already in the 9 th century. Their present total length amounts to $1665 \mathrm{kms}$ (Le Ba Thao, 1977).

Economic activity, and especially the cultivation of paddy rice, caused changes of physical and chemical properties of soils to such an extent that even a special type of soils is distinguished, called paddy rice soils.

The denudation balance and the intensity of modern relief forming processes display clear regional differentiation. Thus, seven regions of contemporary relief modelling can be distinguished in Vietnam: the north-eastern region, the north-western region, the Red River delta, the northern region Truong Son, the southern region Tanong Son, the middle coast and the delta of Mekong.

1. The north-eastern region encompasses the areas located to the northeast of the Red River. Relief is being modelled here mainly through karstic processes, washing out, gully erosion and landslips. An important role in transformation of relief is played by the economic activity of man linked with extraction of iron, zinc and wolfram ores, as well as anthracite.

2. The north-western region stretches to the south-west of the Red River. Relief is being modelled here primarily by water erosion, slide processes and carstic processes. An important influence upon the contemporary morphogenesis is exerted by the agricultural economy. This region belongs to the most degraded ones in Vietnam.

3. The Red River delta, together with the deltas of the Thai Binh and Song Ma rivers, have a smoothed out relief, transformed only due to eco- 
nomic activity of man. A marginal role is also played along the coast by the eolic processes.

4. The northern region Truong Son encompasses Hong Son mountains, the limestone range of Ke Bang, Bing Tri Thien mountains and the intramontane bowl of Muong Xen. Relief is being modelled in this region mainly by washing out, gully erosion, landslip processes and carstic processes.

5. The southern region Truong Son encompasses the mountainous areas of southern Vietnam. Relief is being transformed first of all by the washing out, the landslip processes and the gully erosion. In the southern part of the region an important influence upon the course of relief modelling is exerted by the anthropogenic processes connected with the burning of forests and cultivation of the thus cleared land.

6. The middle coast encompasses the belt of coastal lowlands. The cliff coast is modelled by abrasion, while flat shores - by marine accumulation and eolic processes. The relief of the coastal plains is primarily transformed by the anthropogenic processes and by leaching accompanied by washing out.

7. The Mekong delta has a perfectly flat relief. The delta increases its length on the average by $30-40 \mathrm{~mm} /$ year.

Summing up we must state that the most intensive and the most frequent process modelling the relief in Vietnam is water erosion. The intensity of contemporary processes is 5 times bigger than in the past, which is connected with the intervention of man in natural environment.

\section{REFERENCES}

L e B a Tha o, 1977, Thien nhien Viet Nam (Nature of Vietnam; in Vietnamese), Hanoi.

Le Duc An, 1985, Geomorfologiya Vietnama (Geomorphology of Vietnam; in Russian). Academy of Sciences of the USSR. Institute of Geography (D.Sc. dissertation), Moscow.

$\mathrm{Nguyen} \mathrm{Vi} \mathrm{Dan,} \mathrm{1986,} \mathrm{Geomofologiya} \mathrm{ravniny} \mathrm{Bac} \mathrm{Bo} \mathrm{(Geomorphology} \mathrm{of} \mathrm{the} \mathrm{Bac}$ Bo plain; in Russian). State University of M.V.Lomonossov (Ph. D. dissertation), Moscow.

Vi V a n Vi, 1983, Phan vung xoi mon mat luu vuc ve dong chay cat bun trong song Mien Bac Viet Nam (Regionalization of erosion in Northern Vietnam on the basis of analysis of fluvial rubble; in Vietnamese). Manuscript. 
